\title{
The rs2147578 C > G polymorphism in the Inc-LAMC2-1:1 gene is associated with increased neuroblastoma risk in the Henan children
}

Tianyou Yang ${ }^{1}$, Zhuorong Zhang ${ }^{1}$, Jiao Zhang ${ }^{2}$, Tianbao Tan ${ }^{1}$, Jiliang Yang ${ }^{1}$, Jing Pan ${ }^{1}$, Chao Hu ${ }^{1}$, Jiahao Li', Huimin Xia', Jing He ${ }^{1 *}$ and Yan Zou ${ }^{1 *}$ (D)

\begin{abstract}
Background: The rs2147578 C > G polymorphism in the long non-coding RNA gene LnC-LAMC2-1:1 is associated with increased susceptibility to a few types of cancers. However, its role in neuroblastoma has not been evaluated yet.

Methods: We investigated the association between the Inc-LAMC2-1:1 rs2147578 C > G polymorphism and neuroblastoma susceptibility in Chinese Han populations. A total of 393 neuroblastoma cases and 812 healthy individuals from the Henan and Guangdong provinces were enrolled and subjected to genotyping. Odds ratio (OR) and $95 \%$ confidence interval $(\mathrm{Cl})$ were used to determine the strength of the association of interest.

Results: Combined analysis revealed that the Inc-LAMC2-1:1 rs2147578 C > G polymorphism was associated with increased neuroblastoma susceptibility (CG vs. CC: adjusted $\mathrm{OR}=1.33,95 \% \mathrm{Cl}=1.01-1.75, P=0.045 ; \mathrm{CG} / \mathrm{GG}$ vs. CC: adjusted $\mathrm{OR}=1.34,95 \% \mathrm{Cl}=1.03-1.74, P=0.028$ ). In stratification analysis, children under 18 months with rs 2147578 $\mathrm{CG} / \mathrm{GG}$ genotypes had an increased neuroblastoma risk (adjusted $\mathrm{OR}=1.70,95 \% \mathrm{Cl}=1.08-2.67, P=0.022$ ). Females with rs2147578 CG/GG genotypes also had increased neuroblastoma susceptibility (adjusted $\mathrm{OR}=2.08,95 \% \mathrm{Cl}=1.37$ 3.18, $P=0.0007$ ). In addition, children with Inc-LAMC2-1:1 rs2147578 CG/GG genotypes were prone to develop earlier stages of neuroblastoma (adjusted $\mathrm{OR}=1.46,95 \% \mathrm{Cl}=1.01-2.12, P=0.046$ ).
\end{abstract}

Conclusions: The Lnc-LAMC2-1:1 rs2147578 C > G polymorphism may contribute to increased neuroblastoma susceptibility in children of Henan province.

Keywords: rs2147578, Neuroblastoma, Long non-coding RNA, Polymorphism

\section{Background}

Neuroblastoma is the most common malignant extracranial solid tumor in children, accounting for $7-10 \%$ of all tumors $[1,2]$. Neuroblastoma originates from neural crest precursor cells of the sympathetic nervous system and is mainly located in the adrenal medulla, paraspinal ganglia, and sympathetic trunk [3-5]. The outcome of neuroblastoma is affected by several factors such as age of onset, pathological subtype, International Neuroblastoma Staging System (INSS)

\footnotetext{
* Correspondence: hejing198374@gmail.com; hejing@gwcmc.org; 378319696@qq.com; monknut@126.com

'Department of Pediatric Surgery, Guangzhou Women and Children's Medical Center, Guangzhou Medical University, 9 Jinsui Road, Guangzhou 510623, Guangdong, China

Full list of author information is available at the end of the article
}

stage, N-myc status, DNA ploidy, and structural chromosomal aberrations [3-5].

Genetic factors are critically important in neuroblastoma tumorigenesis. Approximately $1 \%$ of the patients have a family history of neuroblastoma, and are carriers of certain genetic mutations. For instance, anaplastic lymphoma kinase $(A L K)$ and $P H O X 2 B$ gene variants are among the predisposing factors to familial neuroblastoma [6-8]. Evidence of genome-wide association studies (GWASs) of sporadic cases also suggests that genetic factors may be involved in the pathogenesis of neuroblastoma $[9,10]$. These studies indicate an important role of genetic characteristics in the tumorigenesis of this disease.

(c) The Author(s). 2018 Open Access This article is distributed under the terms of the Creative Commons Attribution 4.0 International License (http://creativecommons.org/licenses/by/4.0/), which permits unrestricted use, distribution, and reproduction in any medium, provided you give appropriate credit to the original author(s) and the source, provide a link to the Creative Commons license, and indicate if changes were made. The Creative Commons Public Domain Dedication waiver (http://creativecommons.org/publicdomain/zero/1.0/) applies to the data made available in this article, unless otherwise stated. 
Long non-coding RNAs (lncRNAs) are mRNA-like molecules whose genes belong to the non-protein coding genome. LncRNAs are involved in many biological processes such as gene imprinting, epigenetic regulation, translational regulation, splicing, and aging [11-15]. LncRNAs are also involved in apoptosis and cell differentiation, which are critical in tumorigenesis [16, 17]. LncRNAs such as HULC, PCAT-1, HOTAIR, ANRIL, and $H 19$ are found to play important roles in cancer development [17]. Single nucleotide polymorphism (SNP) at HULC is associated with decreased hepatocellular carcinoma risk [18]. GWAS show that neuroblastoma patients with the G allele of SNP rs6939340, which is located in the IncRNA LOC729177 gene, have a high risk of metastasis and poor outcome $[19,20]$. These studies indicate that evaluation of lncRNA gene polymorphism would be of great value in the risk assessment of neuroblastoma.

The rs2147578 $\mathrm{C}>\mathrm{G}$ polymorphism in the lncRNA gene $L n c-L A M C 2-1: 1$ is associated with susceptibility to several types of cancer, and functional polymorphism in lnc-LAMC2-1:1 may confer a high risk of colorectal cancer through affecting miRNA binding [21]. Moreover, the $\operatorname{lnc}-L A M C 2-1: 1$ rs2147578 polymorphism is also considered a possible risk factor for acute lymphoblastic leukemia (ALL) in children [22]. However, few studies have focused on this polymorphism in neuroblastoma. Here we hypothesized that the lnc-LAMC2-1:1 rs214757 $8 \mathrm{C}>\mathrm{G}$ polymorphism may contribute to neuroblastoma susceptibility, and we tested our hypothesis via a case-control study.

\section{Materials and methods Study subjects}

The subjects enrolled were described in previous studies [23, 24]. Briefly, 393 neuroblastoma patients and 812 cancer-free controls were enrolled from two different provinces of China: 275 neuroblastoma patients and 531 controls from the Guangzhou Women and Children's Medical Center in Southern China, and 118 neuroblastoma patients and 281 controls from the Henan province in Northern China $[25,26]$. Diagnosis and clinical stages of neuroblastoma were assigned according to the Shimada system and the international criteria for neuroblastoma staging system [27, 28]. Healthy controls had no history of malignancies and were matched to the neuroblastoma cases in terms of age ( \pm 5 years), gender, ethnicity, and geographical region. Both cases and controls were unrelated Chinese Han individuals living in the Guangdong and Henan provinces of China.

This study was approved by the Institutional Review Board of Guangzhou Women and Children's Medical Center (Guangzhou, China), and written informed consent was obtained from the parents of the participants or their legal guardians for the use of their children's medical data and biological samples.

\section{SNP selection and genotyping}

The Lnc-LAMC2-1:1 rs2147578 C > G polymorphism was genotyped using the TaqMan real-time PCR system on a 7900 Sequence Detection System (Applied Biosystems, Foster City, CA), as described previously [29-31]. Briefly, high-quality DNA samples were genotyped using Taqman real-time PCR method on a 7900 HT sequence detector system. The call rate for the SNPs was 99\%, which met the pre-set criterion. For quality control, eight duplicate positive and eight negative controls without DNA were used in each 384-well plate [32, 33]. Additionally, $10 \%$ samples were randomly selected and repeated, and the reproducibility was $100 \%$ concordant.

\section{Statistical analysis}

All statistical tests were two-sided, with a significance level of $P<0.05$. All statistical analyses were performed using SAS software (Version 9.4; SAS Institute, Cary, NC, USA). Two-sided $\chi^{2}$ tests were used to analyze demographic data and genotype frequencies. The Hardy-Weinberg equilibrium was assessed using the goodness-of- $\chi^{2}$ test. Odds ratios (OR) and 95\% confidence intervals (CIs) were calculated using the Woolf approximation method to evaluate association between the $\operatorname{lnc}-L A M C 2-1: 1 \mathrm{rs} 2147578 \mathrm{C}>\mathrm{G}$ polymorphism and neuroblastoma susceptibility. Crude and age- and gender-adjusted OR were evaluated using the unconditional logistic regression method.

\section{Results}

Demographic characteristics of the study population

A total of 275 cases of neuroblastoma and 531 health controls in Guangdong province and 118 neuroblastoma cases and 281 health controls in Henan province were evaluated (Additional File 1 Table S1). Age and gender distributions were similar between cases and controls in both Guangdong and Henan province subgroups $(P>$ 0.05). Distribution of clinical stages and sites of tumor origin are also listed in Additional file 1 Table S1.

\section{Lnc-LAMC2-1:1 rs2147578 C > G polymorphism and susceptibility to neuroblastoma}

Genotype and allele frequencies of the lnc-LAMC2-1:1 rs2147578 C > G polymorphism and associations with neuroblastoma risk are summarized in Table 1 . In both combined and subgroup analyses, the genotype distribution of the $\operatorname{lnc}-L A M C 2-1: 1$ rs $2147578 \mathrm{C}>\mathrm{G}$ polymorphism in the controls and cases were consistent with Hardy-Weinberg equilibrium $(P=0.164$ for combined subjects, $P=0.279$ for Guangdong province, and $P=0.386$ for Henan province). 
Table 1 Genotype distribution of the Inc-LAMC2-1:1 rs2147578 C > G polymorphism and neuroblastoma susceptibility

\begin{tabular}{|c|c|c|c|c|c|c|c|}
\hline Genotype & Case & Control & $p^{a}$ & $\begin{array}{l}\text { Crude OR } \\
(95 \% \mathrm{Cl})\end{array}$ & $P$ & $\begin{array}{l}\text { Adjusted OR } \\
(95 \% \mathrm{Cl})^{\mathrm{b}}\end{array}$ & $p^{b}$ \\
\hline \multicolumn{8}{|c|}{ Guangdong province $(H W E=0.279)$} \\
\hline $\mathrm{CC}$ & $88(32.00)$ & 195 (36.79) & & 1.00 & & 1.00 & \\
\hline CG & $130(47.27)$ & $243(45.85)$ & & $1.19(0.85-1.65)$ & 0.312 & $1.18(0.85-1.64)$ & 0.332 \\
\hline GG & $57(20.73)$ & $92(17.36)$ & & $1.37(0.91-2.08)$ & 0.135 & $1.38(0.91-2.10)$ & 0.127 \\
\hline Additive & & & 0.305 & $1.17(0.96-1.44)$ & 0.124 & $1.18(0.96-1.44)$ & 0.120 \\
\hline Dominant & $187(68.00)$ & $335(63.21)$ & 0.177 & $1.24(0.91-1.68)$ & 0.177 & $1.23(0.91-1.68)$ & 0.183 \\
\hline Recessive & $218(79.27)$ & $438(82.64)$ & 0.243 & $1.25(0.86-1.80)$ & 0.244 & $1.26(0.87-1.82)$ & 0.223 \\
\hline \multicolumn{8}{|c|}{ Henan province $(\mathrm{HWE}=0.386)$} \\
\hline $\mathrm{CC}$ & $29(24.58)$ & $99(35.36)$ & & 1.00 & & 1.00 & \\
\hline CG & $67(56.78)$ & $129(46.07)$ & & $1.77(1.07-2.95)$ & 0.027 & $1.73(1.03-2.89)$ & 0.037 \\
\hline GG & $22(18.64)$ & $52(18.57)$ & & $1.44(0.76-2.76)$ & 0.266 & $1.42(0.74-2.74)$ & 0.291 \\
\hline Additive & & & 0.085 & $1.25(0.92-1.70)$ & 0.158 & $1.23(0.90-1.69)$ & 0.186 \\
\hline Dominant & $89(75.42)$ & $181(64.64)$ & 0.036 & $1.68(1.03-2.73)$ & 0.037 & $1.64(1.004-2.68)$ & 0.048 \\
\hline Recessive & $96(81.36)$ & $228(81.43)$ & 0.986 & $1.01(0.58-1.75)$ & 0.986 & $1.00(0.57-1.74)$ & 1.000 \\
\hline \multicolumn{8}{|c|}{ Combined $(\mathrm{HWE}=0.164)$} \\
\hline CC & $117(29.77)$ & $294(36.30)$ & & 1.00 & & 1.00 & \\
\hline CG & $197(50.13)$ & $372(45.93)$ & & $1.33(1.01-1.75)$ & 0.042 & $1.33(1.01-1.75)$ & 0.045 \\
\hline GG & $79(20.10)$ & $144(17.78)$ & & $1.38(0.97-1.95)$ & 0.071 & $1.38(0.97-1.95)$ & 0.074 \\
\hline Additive & & & 0.080 & $1.19(1.01-1.41)$ & 0.043 & $1.19(1.004-1.41)$ & 0.045 \\
\hline Dominant & $276(70.23)$ & $516(63.70)$ & 0.025 & $1.34(1.04-1.74)$ & 0.025 & $1.34(1.03-1.74)$ & 0.028 \\
\hline Recessive & $314(79.90)$ & $666(82.22)$ & 0.331 & $1.16(0.86-1.58)$ & 0.331 & $1.16(0.86-1.58)$ & 0.333 \\
\hline
\end{tabular}

${ }^{a} X^{2}$ test for genotype distribution in neuroblastoma cases and cancer-free controls

${ }^{\mathrm{b}}$ Adjusted for age and gender

$O R$ odds ratio, $\mathrm{Cl}$ confidence interval

The values were in bold if the $95 \% \mathrm{Cl}$ excluded 1 , or $P<0.05$

No significant difference in CC, CG, and GG genotype distributions was found in the Guangdong subgroup, indicating that the $L n c-L A M C 2-1: 1$ rs2147578 C > G polymorphism is not associated with neuroblastoma risk in the Guangdong study population. However, the lnc-LAMC2-1:1 rs2147578 C > G polymorphism was associated with increased neuroblastoma risk in the Henan population (CG vs. $\mathrm{CC}$ : adjusted $\mathrm{OR}=1.73,95 \% \mathrm{CI}=$ 1.03-2.89, $P=0.048$; CG/GG vs. $C$ : adjusted $\mathrm{OR}=1.64$, $95 \% \mathrm{CI}=1.004-2.68, P=0.048)$.

The combined analysis showed that the distribution of the CG genotype was significantly higher in the neuroblastoma group (adjusted $\mathrm{OR}=1.33,95 \% \mathrm{CI}=1.01-1.75$, $P=0.045)$, indicating that the $\operatorname{lnc}-L A M C 2-1: 1 \mathrm{rs} 2147578$ CG/GG genotype carriers had an increased risk of neuroblastoma $(\mathrm{CG} / \mathrm{GG}$ vs. $\mathrm{CC}$ : adjusted $\mathrm{OR}=1.34,95 \% \mathrm{CI}=$ $1.03-1.74, P=0.028)$.

Stratification analysis of the Inc-LAMC2-1:1 rs2147578 C > $\mathrm{G}$ polymorphism and neuroblastoma risk

Stratification analyses according to age, gender, site of origin, and clinical stage were further conducted. The
CG/GG genotypes in children younger than 18 months were associated with increased neuroblastoma risk (adjusted $\mathrm{OR}=1.70,95 \% \mathrm{CI}=1.08-2.67, P=0.022$ ). Females with the CG/GG genotypes were associated with increased neuroblastoma risk (adjusted OR $=2.08,95 \%$ $\mathrm{CI}=1.37-3.18, P=0.0007)$. In addition, Individuals with the CG/GG genotypes tended to be in an earlier clinical stage of neuroblastoma (adjusted $\mathrm{OR}=1.46,95 \% \mathrm{CI}=1.01$ 2.12, $P=0.046)$. Finally, no significant association between the lnc-LAMC2-1:1 rs2147578 C>G polymorphism and the site of tumor origin was found (Table 2).

\section{Discussion}

In this study, we investigated the association between the $\operatorname{lnc}-L A M C 2-1: 1 \mathrm{rs} 2147578 \mathrm{C}>\mathrm{G}$ polymorphism and neuroblastoma susceptibility in Chinese Han populations. We found that the $\operatorname{lnc}-L A M C 2-1: 1$ rs2147578 C > $\mathrm{G}$ polymorphism is associated with increased neuroblastoma susceptibility. Specifically, females and children younger than 18 months with specific genotypes in the lnc-LAMC2-1:1 rs2147578 C > G polymorphism are at an increased risk of neuroblastoma. Fortunately, 
Table 2 Stratification analysis of the association between the Inc-LAMC2-1:1 rs2147578 C > G polymorphism and neuroblastoma susceptibility for combined subjects

\begin{tabular}{|c|c|c|c|c|c|c|}
\hline \multirow[t]{2}{*}{ Variable } & \multicolumn{2}{|c|}{ rs2147578 (case/control) } & \multirow{2}{*}{$\begin{array}{l}\text { Crude OR } \\
(95 \% \mathrm{Cl})\end{array}$} & \multirow[t]{2}{*}{$P$} & \multirow{2}{*}{$\begin{array}{l}\text { Adjusted OR }{ }^{a} \\
(95 \% \mathrm{Cl})\end{array}$} & \multirow[t]{2}{*}{$P^{a}$} \\
\hline & $\overline{C C}$ & $\mathrm{CG} / \mathrm{GG}$ & & & & \\
\hline \multicolumn{7}{|l|}{ Age, month } \\
\hline$\leq 18$ & $35 / 120$ & $91 / 184$ & $1.70(1.08-2.67)$ & 0.022 & $1.70(1.08-2.67)$ & 0.022 \\
\hline$>18$ & $82 / 174$ & $185 / 332$ & $1.18(0.86-1.63)$ & 0.302 & $1.18(0.86-1.62)$ & 0.312 \\
\hline \multicolumn{7}{|l|}{ Gender } \\
\hline Female & $39 / 130$ & $129 / 211$ & $2.04(1.34-3.10)$ & 0.0009 & $2.08(1.37-3.18)$ & 0.0007 \\
\hline Male & $78 / 164$ & $147 / 305$ & $1.01(0.73-1.42)$ & 0.938 & $1.00(0.72-1.40)$ & 0.981 \\
\hline \multicolumn{7}{|l|}{ Site of origin } \\
\hline Adrenal gland & $43 / 294$ & $110 / 516$ & $1.46(1.00-2.13)$ & 0.052 & $1.41(0.96-2.07)$ & 0.077 \\
\hline Retroperitoneal region & $31 / 294$ & $56 / 516$ & $1.03(0.65-1.63)$ & 0.903 & $1.04(0.66-1.66)$ & 0.863 \\
\hline Mediastinum & $32 / 294$ & $77 / 516$ & $1.37(0.89-2.12)$ & 0.157 & $1.39(0.90-2.16)$ & 0.138 \\
\hline Others & $9 / 294$ & $27 / 516$ & $1.71(0.79-3.68)$ & 0.171 & $1.75(0.81-3.78)$ & 0.155 \\
\hline \multicolumn{7}{|l|}{ Clinical stage } \\
\hline $1+\|+4 s$ & $46 / 294$ & $116 / 516$ & $1.44(0.99-2.08)$ & 0.055 & $1.46(1.01-2.12)$ & 0.046 \\
\hline$I I I+I V$ & $68 / 294$ & $143 / 516$ & $1.20(0.87-1.65)$ & 0.272 & $1.16(0.84-1.61)$ & 0.362 \\
\hline
\end{tabular}

${ }^{a}$ Adjusted for age and gender

$O R$ odds ratio; $\mathrm{Cl}$ confidence interval

The values were in bold if the $95 \% \mathrm{Cl}$ excluded 1 , or $P<0.05$

individuals with the CG/GG variation tended to have the earlier stages of neuroblastoma.

Neuroblastoma accounts for approximately $15 \%$ of all childhood cancer mortality, and understanding the underlying mechanisms of this disease would be of great value for diagnosis and treatment $[1,2]$. Genetic variants are critical in neuroblastoma tumorigenesis and disease progression. Missense mutations in $P H O X 2 B$, located on chromosome $4 \mathrm{p}$, were the first germline mutations identified to be associated with neuroblastoma predisposition. Other genetic mutations, such as SNPs in the $A L K$ and BARD1 genes and copy number polymorphism of $N B P F 23$, may also have a role in neuroblastoma development [6-8].

LncRNAs are involved in many biological processes, with LncRNA-MALAT1 and GAS5 being reported to mediate cell invasion, migration, and apoptosis in human neuroblastoma [34, 35]. The lnc-LAMC2-1:1 polymorphism is located in the $L A M C 1$ gene and close to the $L A M C 2$ gene. Rs2147578 is in the first exon of $\operatorname{lnc}-L A M C 2-1: 1$, and the 26th intron of the $L A M C 1$ gene near the $L A M C 2$ gene [21]. Carriers with the $G$ allele have a slightly increased expression of Inc-LAMC2-1:1 through binding between rs2147578G and miR-128-3p [21]. Previous evidence also suggests that the lnc-LAMC2-1:1 rs2147578 C > G polymorphism may contribute to childhood ALL development [22]. Our results show that the lnc-LAMC2-1:1 rs2147578 C > G polymorphism may also be involved in neuroblastoma tumorigenesis.

Abnormal expression of $L A M C 2$ was found in several types of cancer, and elevated expression of $L A M C 2$ is associated with poor clinical outcome and relapse [36, 37].
$L A M C 2$ can interact with the epidermal growth factor receptor $(E G F R)$, and influence its downstream pathway [38]. Previous studies revealed that the EGF receptor is overexpressed in neuroblastoma tissues and cells, and anti-EGFR agents are potential targeted therapies for neuroblastoma [39-41]. The possible interaction between the $\operatorname{lnc}-L A M C 2$ 1:1 rs2147578 polymorphism and the EGFR pathway may account for the increased risk of neuroblastoma of the $G$ allele.

Our results from Guangdong (Southern China) and Henan (Northern China) provinces were inconsistent. In the Henan province subgroup, the CG genotype distribution was significantly higher in the neuroblastoma group, and subjects with the GG and CG genotypes had a significantly increased risk of neuroblastoma. In contrast, no association between the $\mathrm{G}$ allele and neuroblastoma was found in the Guangdong province subgroup. A possible explanation for this inconsistency may be the relatively complex genetic background of the Guangdong Chinese Han population. Studies on Y-chromosome phylogeny suggest that people in Southern China, including Guangdong province, are much more polymorphic than populations in Northern China, including Henan province [42-44]. However, the relatively small sample size of our study may introduce bias.

\section{Conclusion}

The Lnc-LAMC2-1:1 rs2147578 C > G polymorphism is associated with increased neuroblastoma susceptibility in Han populations of Northern China. Female individuals and children younger than 18 months with such genetic variants are 
at an increased risk for neuroblastoma. But with samples collected from only two provinces, we can't make any solid conclusion. We might look into this question in the near future when we collect more samples.

\section{Additional file}

Additional file 1: Table S1. Clinical characteristics of neuroblastoma cases and cancer-free controls. (DOCX $15 \mathrm{~kb}$ )

\section{Abbreviations}

ALK: Anaplastic lymphoma kinase; ALL: Acute lymphoblastic leukemia; $\mathrm{Cl}$ : Confidence interval; EGFR: Epidermal growth factor receptor; GWAS: Genome-wide association study; INSS: International Neuroblastoma Staging System; LncRNA: Long non-coding RNAs; OR: Odds ratio; SNP: Single nucleotide polymorphism

\section{Funding}

This study was funded by the Pearl River S\&T Nova Programme of Guangzhou (No: 201710010086), the National Natural Science Foundation of China (No: 81602199), the Guangzhou Science Technology and Innovation Commission (No: 201607010395), the Natural Science Foundation of Guangdong Province, China (No: 2016A030313496), and National Natural Science Foundation of China (No: 81602199). The funding body has no role in the design of the study and collection, analysis, and interpretation of data and in writing the manuscript.

\section{Availability of data and materials}

The datasets used during the current study are available from the corresponding author on reasonable request.

\section{Authors' contributions}

TY, JH, YZ made substantial contributions to conception and design of this study. ZZ, JZ, TT, JP, CH, and JL make substantial contribution to the acquision of data, and interpretation of data. TY, JH, JY, and HX made substantial contribution to statistical analysis and interpretation of data. TY, $S L, Y Z$ had been involved in drafting the manuscript and revising it critically for important intellectual content. $\mathrm{YZ}$ and $\mathrm{JH}$ were agreed to be accountable for all aspects of the work in ensuring that questions related to the accuracy or integrity of any part of the work are appropriately investigated and resolved. TY, and $Z Z$ contributed to the work equally. All authors had given final approval of the version to be published.

\section{Ethics approval and consent to participate}

This study was approved by the Institutional Review Board of Guangzhou Women and Children's Medical Center (Guangzhou, China). Written informed consent was obtained from the parents of the participants or their legal guardians for the use of their children's medical data and biological samples. All patient records/data were anonymized and de-identified prior to analysis.

\section{Consent for publication}

Not applicable.

\section{Competing interests}

The authors declare that they have no competing interests.

\section{Publisher's Note}

Springer Nature remains neutral with regard to jurisdictional claims in published maps and institutional affiliations.

\section{Author details}

'Department of Pediatric Surgery, Guangzhou Women and Children's Medical Center, Guangzhou Medical University, 9 Jinsui Road, Guangzhou 510623, Guangdong, China. ${ }^{2}$ Department of Pediatric Surgery, The First Affiliated Hospital of Zhengzhou University, Zhengzhou 450052, Henan, China.
Received: 28 March 2018 Accepted: 21 September 2018

Published online: 03 October 2018

\section{References}

1. Brodeur GM. Neuroblastoma: biological insights into a clinical enigma. Nat Rev Cancer. 2003;3:203-16.

2. Kamijo T, Nakagawara A. Molecular and genetic bases of neuroblastoma. Int J Clin Oncol. 2012;17:190-5.

3. Bagatell R, Beck-Popovic M, London WB, Zhang Y, Pearson AD, Matthay KK, et al. Significance of MYCN amplification in international neuroblastoma staging system stage 1 and 2 neuroblastoma: a report from the international neuroblastoma risk group database. J Clin Oncol. 2009;27:365-70.

4. Cohn SL, Pearson AD, London WB, Monclair T, Ambros PF, Brodeur GM, et al. The international neuroblastoma risk group (INRG) classification system: an INRG task force report. J Clin Oncol. 2009:27:289-97.

5. Monclair T, Brodeur GM, Ambros PF, Brisse HJ, Cecchetto G, Holmes K, et al. The international neuroblastoma risk group (INRG) staging system: an INRG task force report. J Clin Oncol. 2009;27(2):298-303.

6. Trochet D, O'Brien LM, Gozal D, Trang H, Nordenskjold A, Laudier B, et al. PHOX2B genotype allows for prediction of tumor risk in congenital central hypoventilation syndrome. Am J Hum Genet. 2005;76:421-6.

7. McConville C, Reid S, Baskcomb L, Douglas J, Rahman N. PHOX2B analysis in non-syndromic neuroblastoma cases shows novel mutations and genotypephenotype associations. Am J Med Genet A. 2006;140:1297-301.

8. Mosse YP, Laudenslager M, Longo L, Cole KA, Wood A, Attiyeh EF, et al. Identification of ALK as a major familial neuroblastoma predisposition gene. Nature. 2008;455:930-5.

9. Caren H, Abel F, Kogner P, Martinsson T. High incidence of DNA mutations and gene amplifications of the ALK gene in advanced sporadic neuroblastoma tumours. Biochem J. 2008:416:153-9.

10. George RE, Sanda T, Hanna M, Frohling S, Luther W, 2nd, Zhang J, et al. Activating mutations in ALK provide a therapeutic target in neuroblastoma. Nature 2008:455:975-978.

11. Rando TA, Chang HY. Aging, rejuvenation, and epigenetic reprogramming: resetting the aging clock. Cell. 2012;148:46-57.

12. Batista PJ, Chang HY. Long noncoding RNAs: cellular address codes in development and disease. Cell. 2013:152:1298-307.

13. Prensner JR, Chinnaiyan AM. The emergence of IncRNAs in cancer biology. Cancer Discov. 2011;1:391-407.

14. Mattick JS. Non-coding RNAs: the architects of eukaryotic complexity. EMBO Rep. 2001;2:986-91.

15. Jeon $Y$, Sarma K, Lee JT. New and Xisting regulatory mechanisms of $X$ chromosome inactivation. Curr Opin Genet Dev. 2012;22:62-71.

16. Wapinski $\mathrm{O}$, Chang HY. Long noncoding RNAs and human disease. Trends Cell Mol Biol. 2011;21:354-61

17. Pandey RR, Kanduri C. Transcriptional and posttranscriptional programming by long noncoding RNAs. Prog Mol Subcell Biol. 2011;51:1-27.

18. Liu Y, Pan S, Liu L, Zhai X, Liu J, Wen J, et al. A genetic variant in long noncoding RNA HULC contributes to risk of HBV-related hepatocellular carcinoma in a Chinese population. PLoS One. 2012;7:e35145.

19. Maris JM, Mosse YP, Bradfield JP, Hou C, Monni S, Scott RH, et al. Chromosome 6p22 locus associated with clinically aggressive neuroblastoma. N Engl J Med. 2008;358:2585-93.

20. Diskin SJ, Capasso M, Schnepp RW, Cole KA, Attiyeh EF, Hou C, et al. Common variation at $6 q 16$ within HACE1 and LIN28B influences susceptibility to neuroblastoma. Nat Genet. 2012;44:1126-30.

21. Gong J, Tian J, Lou J, Ke J, Li L, Li J, et al. A functional polymorphism in InCLAMC2-1:1 confers risk of colorectal cancer by affecting miRNA binding. Carcinogenesis. 2016:37:443-51

22. Hashemi M, Bahari G, Naderi M, Sadeghi-Bojd S, Taheri M. Association of IncLAMC2-1:1 rs2147578 and CASC8 rs10505477 polymorphisms with risk of childhood acute lymphoblastic leukemia. Asian Pac J Cancer Prev. 2016;17:4985-9.

23. He J, Zou Y, Liu X, Zhu J, Zhang J, Zhang R, et al. Association of common genetic variants in pre-microRNAs and neuroblastoma susceptibility: a two-center casecontrol study in Chinese children. Mol Ther Nucleic Acids. 2018;11:1-8.

24. Zhang Z, Chang Y, Jia W, Zhang J, Zhang R, Zhu J, et al. LINC00673 rs11655237 C>T confers neuroblastoma susceptibility in Chinese population. Biosci Rep. 2018:38:BSR20171667.

25. Zhang J, Lin H, Wang J, He J, Zhang D, Qin P, et al. LMO1 polymorphisms reduce neuroblastoma risk in Chinese children: a two-center case-control study. Oncotarget. 2017;8:65620-6. 
26. Zhang J, Zhuo ZJ, Wang J, He J, Yang L, Zhang D, et al. CASC15 gene polymorphisms reduce neuroblastoma risk in Chinese children. Oncotarget. 2017;8:91343-9.

27. Shimada H, Ambros IM, Dehner LP, Hata J, Joshi W, Roald B, et al. The international neuroblastoma pathology classification (the Shimada system). Cancer. 1999;86:364-72.

28. Brodeur GM, Pritchard J, Berthold F, Carlsen NL, Castel V, Castelberry RP, et al. Revisions of the international criteria for neuroblastoma diagnosis, staging, and response to treatment. J Clin Oncol. 1993;11:1466-77.

29. Gong J, Tian J, Lou J, Wang X, Ke J, Li J, et al. A polymorphic MYC response element in KBTBD11 influences colorectal cancer risk, especially in interaction with a MYC regulated SNP rs6983267. Ann Oncol. 2018;29:632-9.

30. Li J, Zou L, Zhou Y, Li L, Zhu Y, Yang Y, et al. A low-frequency variant in SMAD7 modulates TGF-beta signaling and confers risk for colorectal cancer in Chinese population. Mol Carcinog. 2017:56:1798-807.

31. Lou J, Gong J, Ke J, Tian J, Zhang Y, Li J, et al. A functional polymorphism located at transcription factor binding sites, rs6695837 near LAMC1 gene, confers risk of colorectal cancer in Chinese populations. Carcinogenesis. 2017;38:177-83.

32. He J, Qiu LX, Wang MY, Hua RX, Zhang RX, Yu HP, et al. Polymorphisms in the XPG gene and risk of gastric cancer in Chinese populations. Hum Genet. 2012;131:1235-44.

33. He J, Wang F, Zhu J, Zhang R, Yang T, Zou Y, et al. Association of potentially functional variants in the XPG gene with neuroblastoma risk in a Chinese population. J Cell Mol Med. 2016;20:1481-90.

34. Bi S, Wang C, Li Y, Zhang W, Zhang J, Lv Z, et al. LncRNA-MALAT1-mediated Axl promotes cell invasion and migration in human neuroblastoma. Tumour Biol. 2017;39:1010428317699796.

35. Mazar J, Rosado A, Shelley J, Marchica J, Westmoreland TJ. The long noncoding RNA GAS5 differentially regulates cell cycle arrest and apoptosis through activation of BRCA1 and p53 in human neuroblastoma. Oncotarget. 2017:8:6589-607.

36. Takahashi S, Hasebe T, Oda T, Sasaki S, Kinoshita T, Konishi M, et al. Cytoplasmic expression of laminin gamma2 chain correlates with postoperative hepatic metastasis and poor prognosis in patients with pancreatic ductal adenocarcinoma. Cancer. 2002;94:1894-901.

37. Yamamoto H, Itoh F, Iku S, Hosokawa M, Imai K. Expression of the gamma(2) chain of laminin-5 at the invasive front is associated with recurrence and poor prognosis in human esophageal squamous cell carcinoma. Clin Cancer Res. 2001;7:896-900.

38. Garg M, Kanojia D, Okamoto R, Jain S, Madan V, Chien W, et al. Laminin-5 gamma-2 (LAMC2) is highly expressed in anaplastic thyroid carcinoma and is associated with tumor progression, migration, and invasion by modulating signaling of EGFR. J Clin Endocrinol Metab. 2014;99:E62-72.

39. Evangelopoulos ME, Weis J, Kruttgen A. Signalling pathways leading to neuroblastoma differentiation after serum withdrawal: HDL blocks neuroblastoma differentiation by inhibition of EGFR. Oncogene. 2005;24:3309-18.

40. Michaelis M, Bliss J, Arnold SC, Hinsch N, Rothweiler F, Deubzer HE, et al. Cisplatin-resistant neuroblastoma cells express enhanced levels of epidermal growth factor receptor (EGFR) and are sensitive to treatment with EGFRspecific toxins. Clin Cancer Res. 2008;14:6531-7.

41. Zheng C, Shen R, Li K, Zheng N, Zong Y, Ye D, et al. Epidermal growth factor receptor is overexpressed in neuroblastoma tissues and cells. Acta Biochim Biophys Sin. 2016;48:762-7.

42. Deng W, Shi B, He X, Zhang Z, Xu J, Li B, et al. Evolution and migration history of the Chinese population inferred from Chinese Y-chromosome evidence. J Hum Genet. 2004:49:339-48.

43. Shen P, Wang F, Underhill PA, Franco C, Yang WH, Roxas A, et al. Population genetic implications from sequence variation in four $Y$ chromosome genes. Proc Natl Acad Sci U S A. 2000;97:7354-9.

44. Underhill $P A$, Shen $P$, Lin $A A$, Jin $L$, Passarino $G$, Yang $W H$, et al. $Y$ chromosome sequence variation and the history of human populations. Nat Genet. 2000;26:358-61.

Ready to submit your research? Choose BMC and benefit from:

- fast, convenient online submission

- thorough peer review by experienced researchers in your field

- rapid publication on acceptance

- support for research data, including large and complex data types

- gold Open Access which fosters wider collaboration and increased citations

- maximum visibility for your research: over $100 \mathrm{M}$ website views per year

At BMC, research is always in progress.

Learn more biomedcentral.com/submissions 